\title{
Cultural Influence On The Diffusion And Adoption Of Social Media Technologies By Entrepreneurs In Rural South Africa \\ Lawrence Mpele Lekhanya, Durban University of Technology, South Africa
}

\begin{abstract}
This paper examines how culture influences the diffusion and adoption of social media technologies in rural businesses. The cultural factors influencing the diffusion and adoption of social media technologies among the rural communities in South Africa are still not clear. The study aimed to determine cultural factors influencing diffusion and adoption of social media technologies by rural businesses in KwaZulu-Natal (KZN). Data was collected from five rural areas in KZN. The sample consisted of 175 business owners/managers, selected using quota sampling, with respondents completing a questionnaire with the assistance of an interviewer. A mixed approach of qualitative and quantitative techniques was used. Results of the survey reveal that the majority of respondents indicate that they do consider their cultural values as most important when diffusing and adopting new social media technologies such as Facebook, Twitter, and MXit. Further research should aim to develop training programmes that will provide community entrepreneurial skills and encourage an entrepreneurial spirit and use of new social media technologies among rural dwellers particularly in KZN.
\end{abstract}

Keywords: Cultural; Diffusion; Adoption; Social Media; Community Entrepreneurial Skills; Spirit

\section{INTRODUCTION}

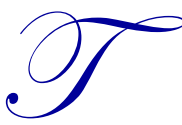

he development of science and technology obstacles does not depend only on the form of the innovation itself, but socio-cultural aspects play a fundamental role in the diffusion and the adoption of innovation (Deligiannaki \& Ali, 2011). Cultural factors, such as individualism and uncertainty, should be considered in order to optimize the efforts and maximize innovation diffusion (Tolba \& Mourad, 2013). According to Straub (1994) cultural effects seem to play an important role in the predisposition towards the selection of electronic communications. Diffusion processes of new products and services have become increasingly complex and multifaceted in recent years. Consumers today are exposed to a wide range of influences that include word-ofmouth communications, network externalities and social signals (Peres, Muller \& Mahajan, 2010). Literature further indicates that Technology adoption climates in developing countries are, by nature, problematic, characterized by poor business and governance conditions, low educational levels, and inappropriate infrastructure (Irura \& Munjiru, 2013).

\section{PROBLEM STATEMENT}

Much research has been done on social media technologies. Although social media technologies are used internationally, no research has yet been done to evaluate how culture influences the diffusion and adoption of social media technologies in rural businesses. Literature suggests that rural businesses tend to have weaker technology adoption than those located in urban settings (Rcino, Frew and Saez, 2013). According to Irura \& Munjiru (2013), culture tends to affect the extent to which small and medium enterprises (SMEs) adopt the use of technology. AlJabri and Sohail (2012) support the premise that not many studies investigate the cultural factors that may assist rural business communities to decide on a strategic approach suitable for diffusion and adoptable by rural communities. 


\section{AIM AND OBJECTIVE}

\section{Aim}

This paper aims to describe and discuss various cultural factors which influence the rate of diffusion and the rate of adoption of social media technologies in rural businesses.

\section{Objectives}

- $\quad$ To determine cultural factors influencing diffusion and adoption of social media technologies in rural businesses;

- To examine the diffusion and adoption rate of social media technologies in rural businesses; and

- $\quad$ To recommend strategies that can assist in improving the diffusion and adoption rate of social media technologies in rural businesses.

\section{LITERATURE REVIEW}

\section{Social Networking (SN) Technologies}

Social networking (SN) technologies are applications that enable the process of connecting people, based on social ties and bonds (Veltri and Elagarah, 2009). Boyd \& Ellison (2007) define social networks sites as webbased services that allow individuals to construct a public or semi - public profile within a bounded system, articulate the list of other users with whom they share a connections, as well as view and traverse their list of connections and those made by others within the system. On the other hand, according to Veltri \& Elagarah (2009), social networking $(\mathrm{SN})$ technologies are applications that enable the process of connecting people based on social ties and bonds. Thus, people are connected with the cultural values, norms and beliefs. This means that Social networking technologies should take account into the people's values, norms, beliefs and Religion. Awolusi (2012) support the premise that social networking websites could heavily influence organizational productivity outcomes, in terms of effective collaboration, across geographical and hierarchical works structures, through the marketing of its products, place and its visibility in the increasingly crowded world of online commerce. If cultural values are not full considered marketing of businesses through social networking websites will have big problems. Literature indicates that national culture is likely to play a role in information technology product adoption such as social media and social networks. Recent study shows studies indicate that Facebook has become a major online venue among the younger Arabic young generation; however, the understanding of its adoption as well as, and the cultural influence thereof, remains in its infancy (Shakir and Shen, 2009).

\section{Social Networks in the South Africa Context}

According to UNICEF New York (2012), South Africa is the leading innovator, in Africa, in social networking, micro blogging, and content creation. This does not indicate if rural areas of South Africa are also included. Therefore, this might not be the case in the rural areas of KZN. Van Rijswijck (2013) maintains that social media has gone mainstream in South Africa, with both individuals and businesses embracing the available platforms and, with the average age of users steadily increasing as more people become connected and networks mature. This claim supported by the latest statistics from research house World Wide Worx, 7.9 million of South Africa's 8.5 million internet users go online using their cell phones. It was found that 2.48 million users only use a cell phone, and estimated that smartphone users would increase to 11 million plus in 2012, from a previous estimate of 8.5 million (Clark, 2012). Boris urban (2011) indicates that social networks are assets for small business owners/managers struggling to survive in a competitive market. However, Björn-Sören Gigler (2011) argues that Information and Communication Technologies (ICTs) lead to improvements in people's lives only when informational capabilities are transformed into expanded human and social capabilities in the economic, political, social, organizational and cultural dimensions of their lives (Gigler, 2011). 


\section{Diffusion and Adoption}

Diffusion is a macro process concerned with the spread of a new product from its source to the consuming public, in construct. In theory, adoption is a micro process that focuses on the stage through which an individual consumer passes, when deciding to accept or reject a new product (Schiffman \& Kanuk, 2010). Dearing (2009) describes diffusion as the process that includes presentation of the new culture elements of cultural elements to the society, acceptance of these elements by society and the integration of the accepted element or elements into the existing culture. It has been indicated that norms and values play a critical part in determining the diffusion and adoption rates of an innovation (Dubois, 1972). The complexity of new technologies' services was found to be the most influentially factor affecting the adoption of social media networks (Al-Ghaith, Sanzogni \&, and Sandhu, 2010). According to Hutto, Trewhitt \& Briscoe (2011) stipulates that the adoption of new technology dependents on many factors such as the type of technology, the context or culture in which the technology is introduced, and the individual decisions by people within that culture.

\section{Culture and Diffusion of Technology Adoption}

Culture is one of the most critical elements that allow people to develop and launch innovative ideas (Fauscette, 2010). Resistance to new ideas, fuelled by fear, lack of knowledge, religious and cultural beliefs and traditional practices, has often been strong and thus knowledge and information accumulated slowly (Naimi and Mark, 2010). According to Herbi \& Dunphy (1998), cultural conditions determine the way in which innovations are adopted. This indicates that cultures which vale creativity, technological ability and higher education, are more successful at adopting innovations. In the case of small, rural communities, where word-of-mouth, social stigma and peer pressures from other community members exist, it may play a remarkable role on the innovation diffusions because the location is associated with different risk dimensions (Piccioni, 2010). The cultural environment is of utmost importance for countries to be innovative (Ferreira, 2010). This means that culture is considered to be the general expression of humanity, and the expression of its creativity. Thus indicates that culture is, while also linked to denoting knowledge, talents, industries, civilisation and values. The objective of the study is to gain a better understanding of cultural influence on creativity can enhance easy, which is seen as a vehicle for economic and social media innovation (K A - European Affairs, 2009). It is important to explore the factors such as cultural values that predict user's acceptance and usage of these technologies to better understand the ability and management of these technologies (Cho et al., in Shanab and Ghaleb, 2010). Diffusion has been identified as one of the major of cultural change and, in turn, geographic and can also be the determinants of technology adoption, such as social networking utility (Aldeman, 2012).

\section{Cultural Influence}

According to Strite and Karahana (2006), differences in cultures may explain differences in perceptions, of the adoption and diffusion of information technologies. People are influenced by others within theirs societies/communities when considering the use of new technologies and this also shapes their attitude towards the usage of new systems (Du., Whinston, Lu and Liu, 2010; Al-Somali, Gholami and Clegg, 2009). This can be interpreted to mean that peoples' decision to adopt a technology includes the external impressions, such as cultural values and norms that people are subject to. Cultural values and norms determine consumers' perception of whether other people believe they should engage in certain behaviour (Pai \& Tu, 2011). Individual persons consider people who are close to him/her, such as family, friends and relatives to him/her, when thinking of using new technology (Cho et al., in Shanab \& Ghaleb, 2010). Literature review indicates that the social/cultural influence is a critical element in understanding innovation diffusion (Venkatesh, Morris, Davis \& Davis, 2003). According to Di Pietro et al. (2012), word-of-mouth is influenced by reference groups and it includes friends, superiors, and IT experts, which in turn play a major role in the adoption of communication technologies. Cultural factors are therefore found to limit the adoption of electronic commerce (Kenneth, Rebecca \& Eunice, 2012). The influence that culture has on the social construction of phenomena such as meanings and practices causes learning to be a fundamentally cultural endeavour (Cheng \& Wong, 1996). Thus, shows that the role of social learning in promoting growth and technology diffusion has been featured in the endogenous growth literature (Romer, 1986). The influence that culture has on the social construction of phenomena, such as meanings and practices, causes learning to be a fundamentally cultural endeavour (Cheng \& Wong, 1996). 


\section{RESEARCH METHODOLOGY}

A survey was conducted to collect data from small business owners operating in rural areas of the KwaZulu-Natal Province, in South Africa. Primary data was collected from 175 owners/managers of small businesses in rural KZN. A literature review was used as the source of information from which to formulate the questionnaire, which consisted of both closed-ended and open-ended questions. Space was provided at the end of each question to facilitate the inclusion of any additional open-ended questions, in order to acquire relevant information. A non-probability sampling method, in the form of quota sampling, was used to obtain the desired sample. Quota sampling was used due to time and financial constraints. The final usable sample is shown in Table 1 in terms of quota control characteristics. A mixed approach of qualitative and quantitative techniques was used to collect primary data. In order to standardize the conditions under which the questionnaires were completed, research assistants from local villages in the selected areas were recruited and trained as fieldworkers. Questionnaires were hand delivered to the 175 small business owners/managers, with interviews conducted in the areas of Empangeni, Ulundi, Nquthu, Escourt and Kwa-Nongoma. The respondents' ability to answer the questionnaire was increased by the provision of a number of instructions throughout the questionnaire, which was personally administered. The sample quotas were based on three categories of area of the business, number of employees and turnover per year. The profile of the final usable sample was as show in Table 1:

Table 1: Profile of Usable Sample as per Quota Characteristics

\begin{tabular}{|l|c|c|}
\hline \multicolumn{1}{|c|}{ Geographic Area } & Frequency & Percent \\
\hline Empangeni & 38 & 22 \\
\hline Ulundi & 44 & 25 \\
\hline Nquthu & 32 & 18 \\
\hline Escourt & 36 & 21 \\
\hline Kwa-Nongoma & 25 & 14 \\
\hline Total & 175 & 100 \\
\hline Business Size & & Percent \\
\hline \multicolumn{1}{|c|}{ Turnover per Annum (Turnover per year) } & Frequency & 7 \\
\hline R0-5000 & 12 & 18 \\
\hline R5001-10000 & 32 & 14 \\
\hline R10001-15000 & 24 & 55 \\
\hline Over R15001 & 96 & 6 \\
\hline Don't know & 11 & \\
\hline
\end{tabular}

Table 1: Respondents were asked to indicate area of their businesses and their turnover per year. In this regard turnover is their sales revenue per year.

Table 2.

Questionnaire was used as measuring instrument for this survey. The main questions are summarised in

Table 2: Summary of Key Questions

\begin{tabular}{|l|l|}
\hline \multicolumn{1}{|c|}{ Research Area } & \multicolumn{1}{c|}{ Question } \\
\hline Type of Business & $\begin{array}{l}\text { Type of Business in Which Respondents are Involved? } \\
\text { Response Alternatives: Agriculture; Mining and Quarrying; Manufacturing; Construction; Retail and } \\
\text { Motor Trade Repair Services; Wholesale Trade Commercial Agents and Allied Services; Catering, } \\
\text { Accommodation and Others, Transport, Storage and Communications; Finance and Business } \\
\text { Services; Community, Social and Person Services }\end{array}$ \\
\hline Years of Existence & $\begin{array}{l}\text { Number of Year of the Business Existence? } \\
\text { Response Alternatives: Less than 1 year; 1-2 years; 3-5 years; 6-8 years; more than 10 years }\end{array}$ \\
\hline $\begin{array}{l}\text { How Business } \\
\text { Owned }\end{array}$ & $\begin{array}{l}\text { How Respondents Owned their Business? } \\
\text { Response Alternatives: Jointly Owned; Manager of the Business and Sole Owned; Manager of the } \\
\text { Business and Jointly Owned }\end{array}$ \\
\hline $\begin{array}{l}\text { Do respondents } \\
\text { consider their value, } \\
\text { norms and beliefs }\end{array}$ & $\begin{array}{l}\text { Do Respondents Consider Their Value, Norms and Beliefs Before Using New Social Media } \\
\text { Networks Technologies? } \\
\text { Response Alternatives: Strongly Agree; Agree; Neutral; Disagree; Strongly Disagree }\end{array}$ \\
\hline
\end{tabular}


Table 2 cont.

\begin{tabular}{|l|l|}
\hline $\begin{array}{l}\text { Do respondents } \\
\text { perceive their } \\
\text { cultural values } \\
\text { important }\end{array}$ & $\begin{array}{l}\text { Do Respondents Perceive Their Cultural Values Important Than Using New Social Media } \\
\text { Technologies? } \\
\text { Response Alternatives: Very Important; Important; Somehow Important; Somehow Less Important; } \\
\text { Not Important }\end{array}$ \\
\hline $\begin{array}{l}\text { Attitudes towards } \\
\text { Trust }\end{array}$ & $\begin{array}{l}\text { Attitude Towards Trust of New Social Media Networks with Regard to Their Cultural Beliefs? } \\
\text { Response Alternatives: Strongly Agree; Agree; Neutral; Disagree; Strongly Disagree }\end{array}$ \\
\hline $\begin{array}{l}\text { Familiarity of new } \\
\text { social media } \\
\text { networks } \\
\text { technologies }\end{array}$ & $\begin{array}{l}\text { Respondents' Familiarity with New Social Media Networks Technologies? } \\
\text { Response Alternatives: Yes; No }\end{array}$ \\
\hline
\end{tabular}

\section{RESEARCH FINDINGS}

A comprehensive literature review was done, (presented in the previous section), on problems experienced by rural entrepreneurs, with regard to the cultural factors influencing the diffusion and adoption of new social network technologies in rural KZN. Completed questionnaires were received from 175 owner/managers in rural KZN ( $\mathrm{n}=175)$ and the key findings of this research reveal the following results:

Table 3: Type of Business in Which Respondents are Involved

\begin{tabular}{|l|c|c|}
\hline \multicolumn{1}{|c|}{ Sector } & No. of Businesses & Percentage: No. of Businesses \\
\hline Agriculture & 23 & $13 \%$ \\
\hline Mining and Quarrying & 3 & $2 \%$ \\
\hline Manufacturing & 1 & $0.6 \%$ \\
\hline Construction & 34 & $19 \%$ \\
\hline Retail and Motor Trade Repair Services & 21 & $12 \%$ \\
\hline Wholesale Trade, Commercial Agents and Allied Services & 32 & $18 \%$ \\
\hline Catering, Accommodation and Other & 15 & $9 \%$ \\
\hline Transport, Storage and Communications & 41 & $23 \%$ \\
\hline Finance and Business Services & 3 & $2 \%$ \\
\hline Community, Social and Personal Services & 2 & $1 \%$ \\
\hline
\end{tabular}

Table 3 shows that the sectors in which respondents operate are widespread across industries. However, the bulk of respondents' businesses fall in Transport, Storage and Communications at 41(23\%), with the number of respondents in Construction being 34 (19 percent), Wholesale Trade Commercial Agents and Allied Services measured 32 (18 percent), while Agriculture and Retail and Motor Trade Repair Services totalled 23 (13 percent) respectively.

Table 4: Number of Years of the Business' Existence

\begin{tabular}{|l|c|c|}
\hline \multicolumn{1}{|c|}{ No of Years in Existence } & No of Businesses in Existence & Percentage for Years of Existence \\
\hline Less than 1 year & 26 & $15 \%$ \\
\hline 1-2 years & 32 & $18 \%$ \\
\hline 3-5 years & 50 & $29 \%$ \\
\hline 6-8 years & 35 & $20 \%$ \\
\hline More than 10 years & 32 & $18 \%$ \\
\hline
\end{tabular}

Table 4 indicates that the sample consists of a large portion of well-established businesses, numbering 50 (29 percent) for those in operation from three to five years, and 35 (20 percent) having been operational from six to eight years. While only 26 (15 percent) businesses were very new and had only been in existence for less than one year, there is a good spread of both newer and older businesses, with each of these totalling 32 (18 percent), at one to two years, and more than 10 years.

Table 5: How Respondents Own Their Business

\begin{tabular}{|l|c|c|}
\hline \multicolumn{1}{|c|}{ How Business Owned } & No of Businesses & Percentage \\
\hline Jointly Owned & 40 & $23 \%$ \\
\hline Manager of the Business and Sole Owned & 78 & $45 \%$ \\
\hline Manager of the Business and Jointly Owned & 57 & $33 \%$ \\
\hline
\end{tabular}


Table 5 indicates that a majority of 78 (45 percent), of selected small businesses in rural KZN are Sole Owned, followed by Manager of the Business and Jointly Owned businesses totalling 57 (33 percent), while less than half are Jointly Owned, measuring 40 (23 percent).

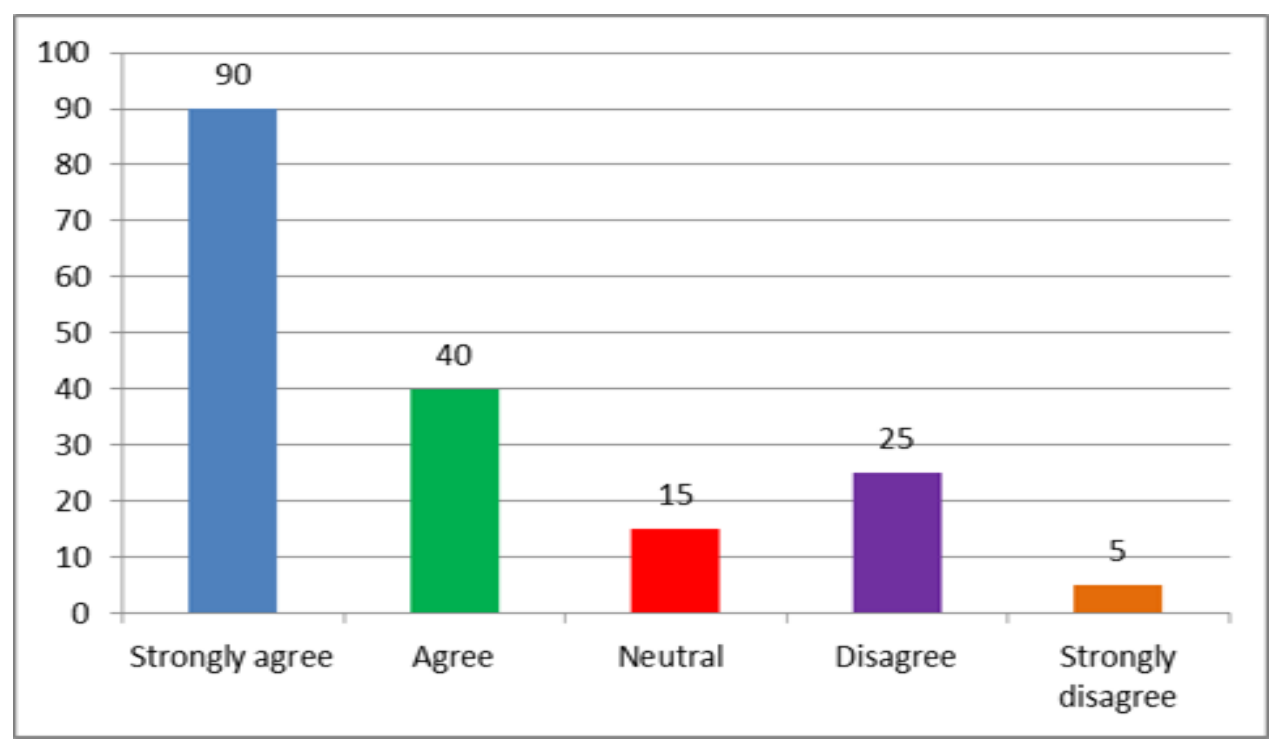

Figure 1: Number of Respondents Who Regard Their Values, Norms and Beliefs as Very Important When Deciding To Use New Social Network Technologies

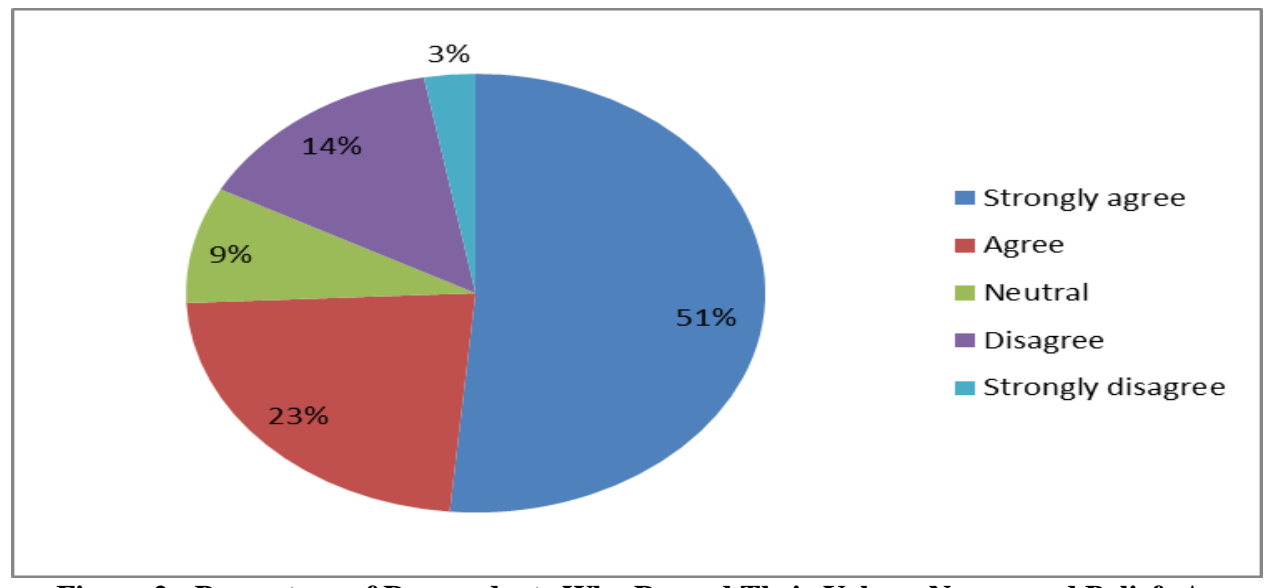

Figure 2: Percentage of Respondents Who Regard Their Values, Norms and Beliefs As Very Important When Deciding To Use New Social Network Technologies

Table 1 and Figure 2 show that on the question of how important values, norms and beliefs are when deciding to use new social media network technologies, in the form of a 5-item Likert scale. Respondents were asked to indicate whether they strongly agree (1), agree (2), are neutral (3), disagree (4) and strongly disagree (5) with the statement. The majority of respondents, across industries, regard their values, norms and beliefs as very important when deciding to use new social network technologies, with 90 (51 percent) strongly agreeing and 40 (23 percent) agreeing with the statement. There are also 15 (nine percent). Respondents who are not sure whether their cultural values are very important when it comes to the use of new social media networks technologies. While very few of the respondents, 25 (14 percent), disagree that culture is important when deciding to use new social media technologies, five (three percent) strongly disagreed with the statement. Based on the statements made, it is clear that culture has an impact on the diffusion and adoption of new social media technologies in rural KZN. 


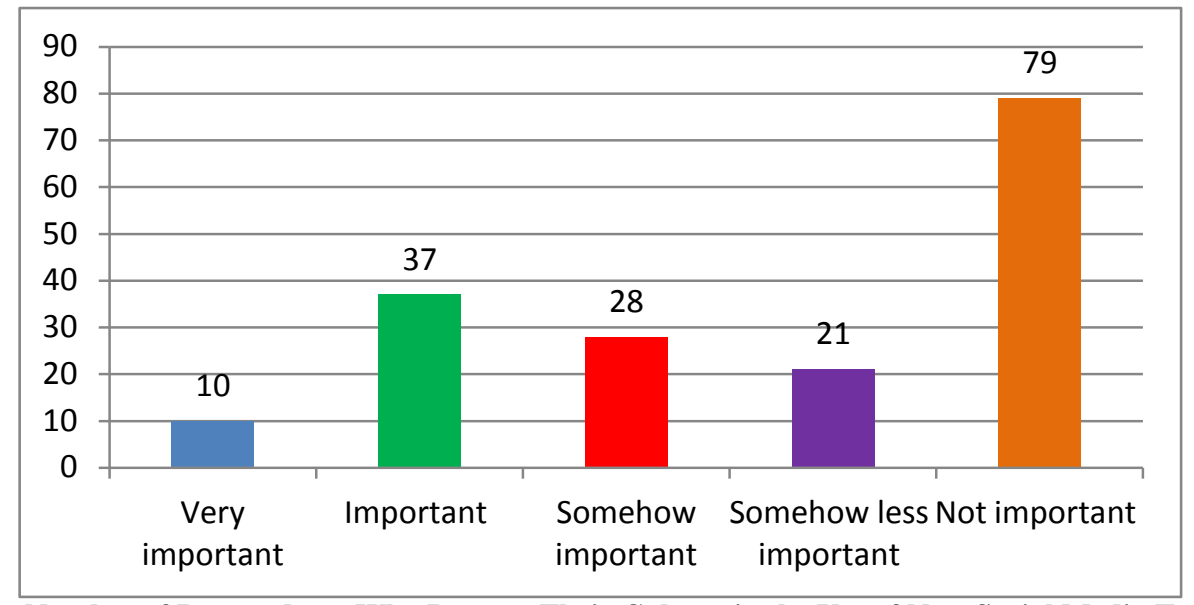

Figure 3: Number of Respondents Who Respect Their Culture in the Use of New Social Media Technologies

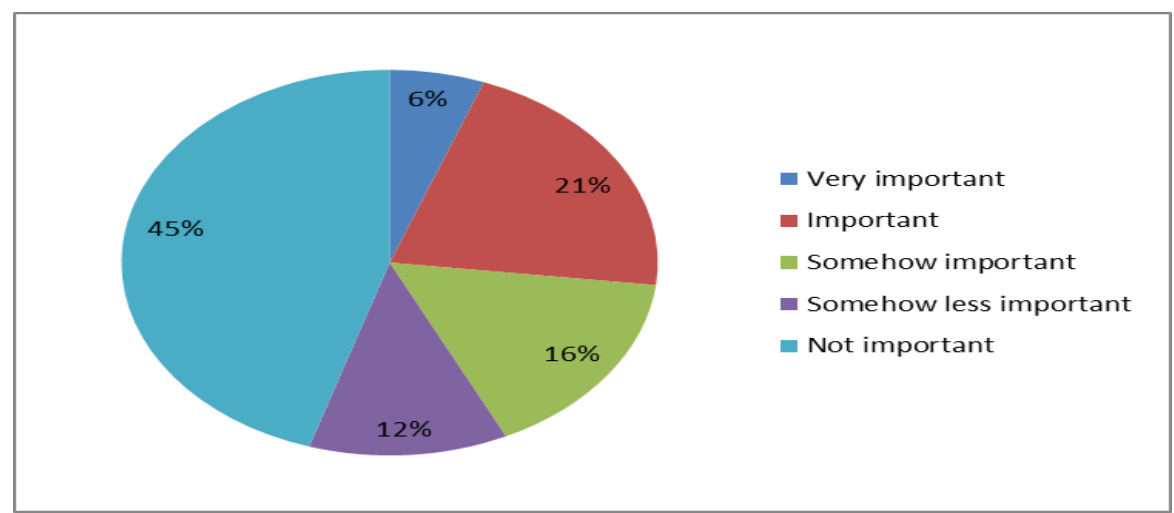

Figure 4: Percentage of Respondents Who Perceived New Social Media Technologies

Figure 3 and Figure 4 illustrate most respondents, 79 (45 percent), do not believe users of social media networking technologies consider their culture as important. However, a small number of 10 (six percent) and 37 (21 percent) believe that social media users do respect their culture and regard it as very important. This indicates that respondents have a perception that social media network users do not regard their culture as an important aspect of social media adoption. The number of respondents who indicated that social media networks users regard their culture as being somehow important and somehow less important, were respectively 28 (16 percent) and 21 (12 percent).

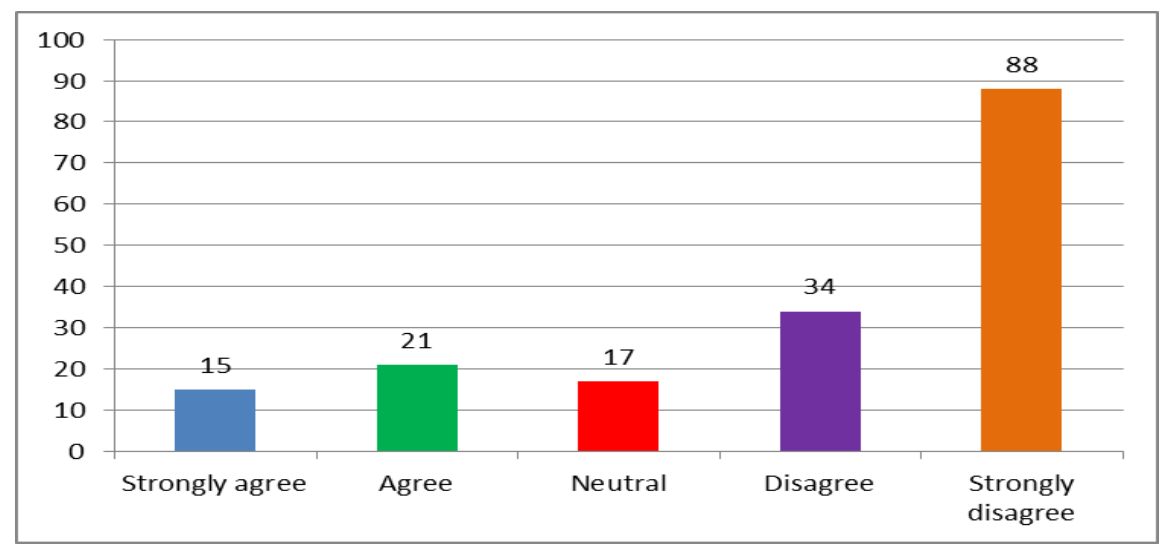

Figure 5: Number of Respondents Attitude towards Trust of New Social Media Networks with Regard To Their Cultural Beliefs 


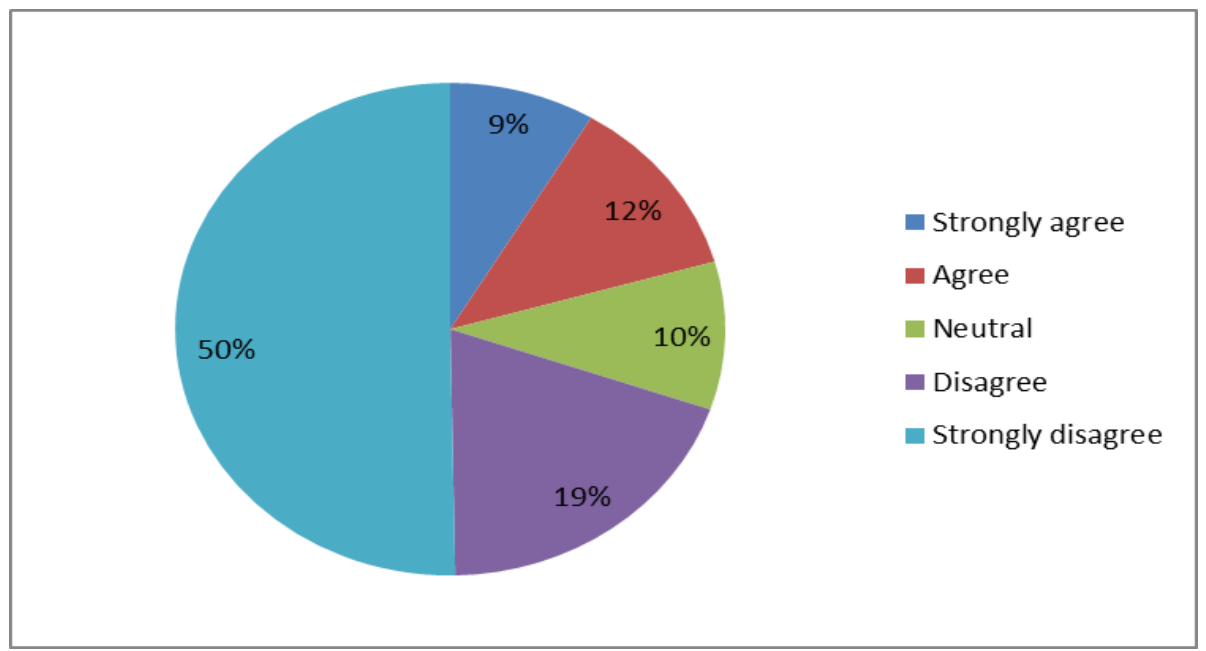

Figure 6: Percentage of Respondents' Attitude towards Trust of New Social Media Networks with Regard To Their Cultural Beliefs

Figure 5 and Figure 6 indicate that the majority of the respondents $88(50 \%)$ and $34(19 \%)$ disagree that new social networks technologies are trustworthy, with regard to their cultural values, norms and beliefs. From the statements that were asked, it is clear that respondents do not trust social media networks when it comes to their cultural beliefs. Less than half of respondents $15(9 \%)$ and $21(12 \%)$ agree that social media networks can be trusted with regard to the cultural value, norms and beliefs. While very few respondents remain neutral $17(10 \%)$.

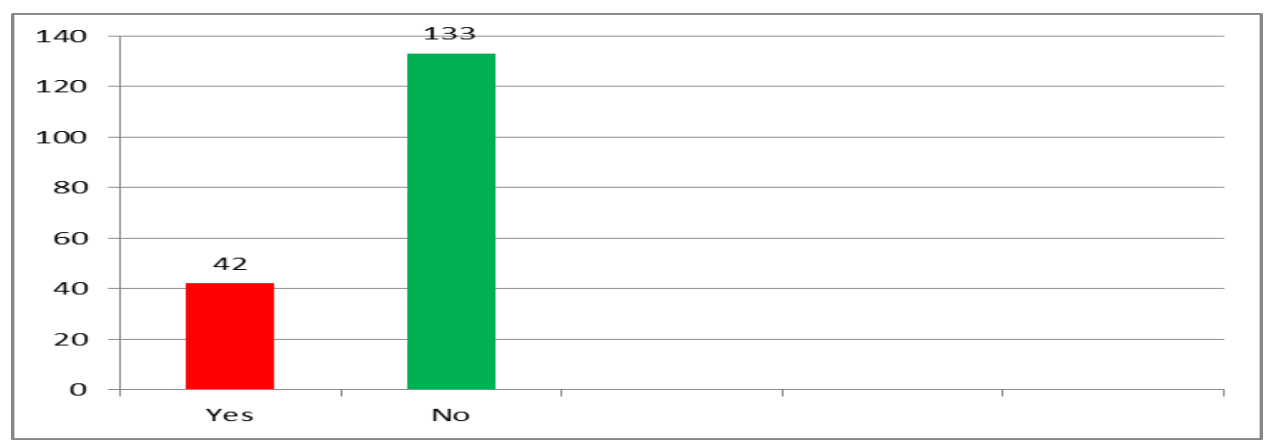

Figure 7: Number of Respondents' Familiarity with New Social Media Networks Technologies

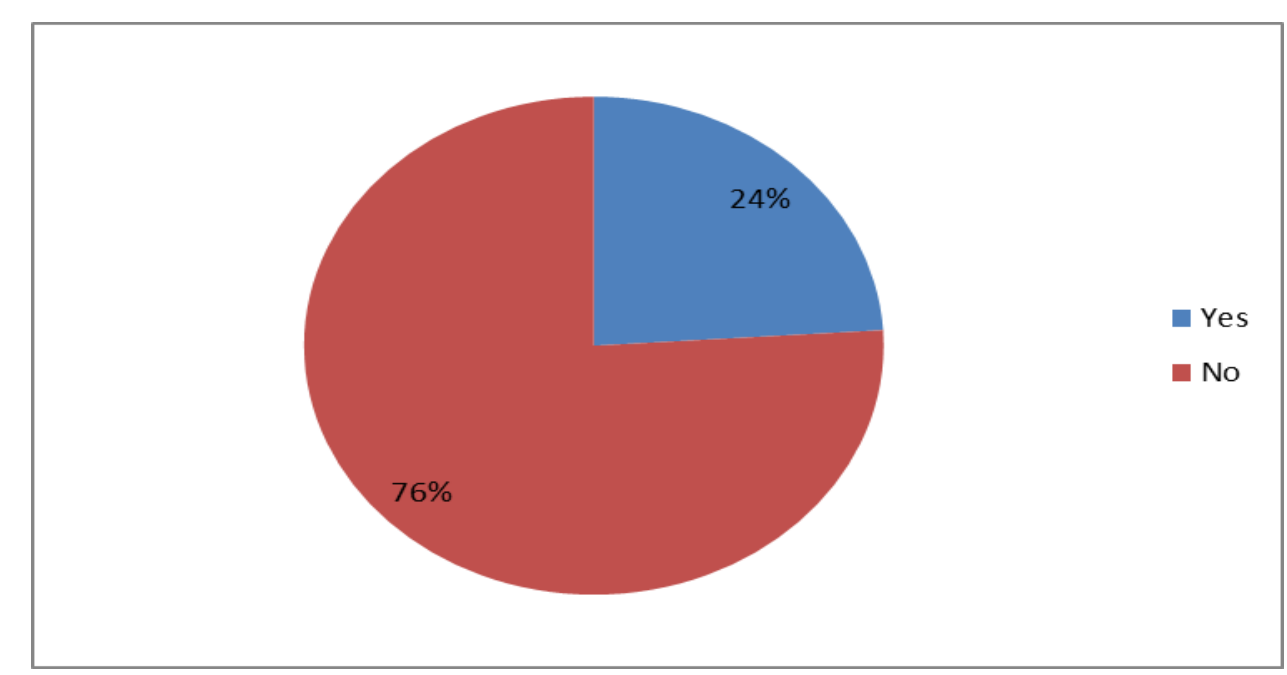

Figure 8: Percentage of Respondents' Familiarity with New Social Media Networks Technologies Copyright by author(s) Creative Commons License CC-BY 
Figure 7 and Figure 8 show that $133(76 \%)$ of the respondents are not familiar and knowledgeable with new social media network technologies, while only $42(24 \%)$ of the respondents indicate that they are familiar and knowledgeable with new social media technologies. From this statement, there is a clear indication that the diffusion and adoption of new social media network technologies is not good.

\section{LIMITATIONS}

This survey did not consider other provinces in South Africa and was confined to rural KZN. Therefore, the results of the study cannot be generalized to the South African population. Due to the complexity of South African geographical profiles, social attributes and economic conditions of rural communities, further research needs to include informal businesses in rural businesses because this survey did not cover this area.

\section{RECOMMENDATIONS}

It is evident from the findings that cultural factors do influence diffusion and adoption of new social media network technologies in the rural areas of KZN. Therefore, this study recommends that training programmes and workshops, targeting small business owners/managers, need to be conducted in order to build awareness and knowledge about the benefit of using social media network technologies as a business tool. Community entrepreneurial training, which focuses on the innovation and use of ICT, should be encouraged in the South African rural areas, including KZN.

\section{CONCLUSIONS}

The understanding of various cultural factors, that influence diffusion and adoption of new social media network technologies, is a major problem facing rural entrepreneurs in KZN. The use of social media networking is rapidly growing in both the business and social sectors of South Africa. Owners/managers in rural KZN should, therefore be made aware of and knowledgeable about cultural factors, which might affect the value of social media and social networking technologies, in promoting their businesses. A lack of understanding and knowledge of the use and importance of social media and social networks among rural entrepreneurial communities have a negative impact, with regard to the diffusion and adoption of new social network technologies, in rural KZN. On the other hand, the lack of awareness, limited knowledge and a lack of broadband accessibility in some areas in rural KZN are the main contributing factors for the poor adoption of these new social technologies.

\section{AUTHOR INFORMATION}

Dr. L. M. Lekhanya is a senior lecturer in the Faculty of Accounting and Informatics at the Durban University of Technology (DUT). He has published a number of articles in refereed journals and is the supervisor for Masters and Doctoral students in many universities in South Africa. He is currently working towards publishing a prescribed textbook on Entrepreneurial marketing. E-mail: lawrencel@dut.ac.za

\section{REFERENCES}

1. Alderman, D.H. (2012). Cultural Change and Diffusion: Geographical Patterns, Social Processes, and Contact Zones. 21st Century Geography: A Reference Handbook (Vol. 1), SAGE Publications.

2. Al-Ghaith, A, W., Sanzogni, L. \& Sandhu, K. (2010). Factors Influencing the Adoption and Usage of Online Services in Saudi Arabia, The Electronic Journal of Information Systems in Developing Countries, Vol. 40.

3. Al-Jabri, I.M. \& Sohail, S.M. (2012). Mobile banking adoption: Application of diffusion of innovation theory, Journal of Electronic Commerce Research, 13(4).

4. Al-Somali, S.A., Gholami, R., \& Clegg. B. (2009). An investigation into the acceptance of online banking in Saudi Arabia. Technovation, 29. Retrieved from: ipac.kacst.edu.sa/edoc/2010/184928_1.pdf

5. Awolusi, F. (2012). The Impacts of Social Networking Sites on Workplace Productivity, Journal of Technology, Management, and Applied Engineering, 28(1). 
6. Boyd, M. \& Ellison, B. (2007). Social networks sites: definition, history and scholarship, Journal of Computer-Mediated Communication, 13(1).

7. Chong, A.Y.L., Ooi, K.B., Lin, B.S., and Raman, M. 2009. Factors affecting the adoption level of ecommerce: An empirical study. Journal of Computer Information Systems, 50(2).

8. Clark, V. 2012. South African social media trends, http://www.twokats.com/2012/06/29/south-africansocial-media-trends/ 25/07/2013.

9. Dearing, J.W. (2009). Applying Diffusion of Innovation Theory to Intervention Development. Retrieved from: www.ncbi.nlm.nih.gov

10. Deligiannaki, A. \& Ali, M. (2011). European, Mediterranean \& Middle Eastern Conference on Information Systems, Cross-Cultural Influence on Diffusion and Adoption of Innovation: An Exploratory Case Study to Investigate the Social-Cultural Barrier, May 30-31, Athens, Greece.

11. Di Pietro, L., Di Virgilio, F. \& Pantano, E. (2012). Social network for the choice of tourist destination: Attitude and behavioural intention. Journal of Hospitality and Tourism Technology, 3(1).

12. Du, H., Whinston, A.B., Lu, T., \& Liu, J. (2010). An empirical study of consumer adoption on mobile data services (MDS) in China. Second International Conference on Multimedia and Information Technology.

13. Dubois, B. (1972). A Cultural Approach to the Study of Diffusion and Adoption of Innovations, in SV Proceedings of the Third Annual Conference of the Association for Consumer Research, eds. Venkatesan, Chicago, IL: Association for Consumer Research.

14. Fauscette, M. 2010. Culture Drives Innovation. Retrieved from: http://www.mfauscette.com/software technology_partn/2010/07/culture-drives-innovation.html

15. Gigler, B. (2011). Informational Capabilities - The Missing Link for the Impact of ICT on development: ETransform Knowledge Platform Working Paper The World Bank, Working Paper Series No. 1.

16. Herbig, P. \& Dunphy, S. (1998). Culture and innovation, Cross cultural management: An International Journal, 5(4).

17. Hutto, C.J., Trewhitt, E \&. Briscoe, E. (2011). Closing the Micro - Macro Divide in Modeling Technology Adoption, Georgia Tech Research Institute Atlanta, GA.

18. Irura, N.S. \& Munjiru, M.M. 2013. Technology Adoption and the Banking Agency in Rural Kenya, Journal of Sociological Research, 4(1).

19. K A -European Affairs. 2009. The impact of culture on creativity. [Online]. Available at: http://ec.europa.eu/culture/documents/study_impact_cult_creativity_06_09.pdf (Accessed 21/02/2013).

20. Kenneth, W.M., Rebecca. N. \& Eunice, M. A. (2012). Factors Affecting Adoption of Electronic Commerce among Small Medium Enterprises in Kenya: Survey of Tour and Travel Firms in Nairobi, International Journal of Business, Humanities and Technology, 2(4).

21. Naimi, L.L. \& Mark, F.R. (2010). The Unintended Consequences of Technological Innovation: Bluetooth Technology and Cultural Change, http://www.internetjournals.net/journals/tir/2010/July/Paper\%2002.pdf

22. Pai, J.C. \& Tu, F.M. 2011. The acceptance and use of customer relationship management (CRM) systems: An empirical study of distribution service industry in Taiwan. Expert Systems with Applications, 38(1).

23. Peterson, M.F., Hart, P. \& Bagchi, K. (2003). National Culture and Information Technology Product Adoption. Retrieved from: papers.synthasite.com/resources/CultureJGITM.doc

24. Peres, M, Muller, E. and Mahajan, V. (2010) Innovation diffusion and new product growth models: A critical review and research directions, International Journal of Research in Marketing, Volume 27, Issue 2, June 2010, Pages 91-106.

25. Piccion, V. (2010). Do the right thing: innovation diffusion and risk dimensions in the passage from conventional to organic agriculture, Journal of central European agriculture, 11(1).

26. Romer, P. (1986). Increasing Returns and Long-Run Growth. Journal of Political Economy, 94(5).

27. Schiffman, L.G. \& Kanuk, L.L. 2010. Consumer behaviour, $10^{\text {th }}$ edition, Pearson.

28. Shakir, M \& Shen, K. (2009). The role of espoused national cultural values in facebook adoption: a replication with Arabic sample. International conference on Electronic Business, Chaninese University of Hong Kong.

29. Straub, D.W. The Effect of Culture on IT Diffusion: E-Mail and FAX in Japan and the U.S. Information Systems Research, 1994 - isr. journal.informs.org

30. Strite, M. (1994). \& Karahana, E., (2006) National Cultural Values in Technology Acceptance, MIS Quarterly, 30(3). 
31. Tolba, A.H. \& Mourad, M. (2013). Individual and cultural factors affecting diffusion of innovation, Journal of International Business and Cultural Studies. Retrieved from: http://www.aabri.com/manuscripts/11806.pdf

32. UNICEF New York. (2012). South African mobile generation: Study on South African young people on mobiles. Retrieved from: http://www.unicef.org/southafrica/SAF_resources_mobilegeneration.pdf

33. Urban, B. (2011). Entrepreneurial networking differences: An ethnic in-group and out-group analysis. $S A$ Journal of Industrial Psychology, 37(1).

34. Van Egmond, M.C., Kühnen, U. \& Li, J. (2013). Retrieved from: http://www.sciencedirect.com/science/article/pii/S2210656113000457

35. Van Rijswijck, E. (2013). http://www.mediaclubsouthafrica.com/index.php?option=com content\&view=article\&id=2652: socialmedia-081111\&catid=49:medianews\&Itemid=113\#ixzz2a3Gws51m

36. Veltri, N.F., Elgarah, W. (2009). The Role of National Cultural Differences in User Adoption of Social Networking, proceedings of the Southern Association of Information Systems Conference, Charleston, SC.

37. Venkatesh, V., Morris, M.G., Davis, G.B. \& Davis, F.D. 2003. User Acceptance of Information Technology: Toward a Unified View. MIS Quarterly, 27(3). 
NOTES 